\begin{tabular}{|c|c|c|}
\hline $\begin{array}{l}\text { JURNALPENELITIAN KEBIDANAN } \\
\text { \& KESPRO }\end{array}$ & VOL. 1 NO. 2 & $\begin{array}{l}\text { EDITION: NOVEMBER } 2018 \text { - } \\
\text { APRIL } 2019\end{array}$ \\
\hline & http://ejournal.delihusada.ac.id/index.php/JPK2R & \\
\hline RECEIVED: 16 JANUARI 2019 & REVISED: 12 MARET 2019 & ACCEPTED: 20 APRIL 2019 \\
\hline
\end{tabular}

\title{
PENGARUH PERAWATAN METODE KANGURU TERHADAP PENINGKATAN SUHU TUBUH BAYI BERAT LAHIR RENDAH DI NICU RUMAH SAKIT GRANDMED LUBUK PAKAM TAHUN 2018
}

\author{
Ika Nur Sapurtri, Dwi Handayani, Maharani Nazmi Nasution \\ Institut Kesehatan Medistra Lubuk Pakam, Jl. Sudirman No.38 Lubuk Pakam \\ Ikanursaputri@gmail.com
}

\begin{abstract}
Babies with low birth weight have a temperature that is unstable and prone to hypothermia (temperature $<36,5^{\circ} \mathrm{C}$ ). Cold stress can increase mortality and hamper growth. The warmth of the mother's body or a known method of kangaroo care proved to be an effective heat source for infants born at term or low birth weight. This study aims to determine whether there is influence kangaroo care method to your body temperature low birth weight infants. This type of research is pre experiment with models (one group pre-post test design). The population of this research is all low birth weight babies. Sampling techniques in use purposive sampling, that the sampling technique was based on sample criteria specified by the researchers themselves. In this case the samples found as many as 22 people. Data analysis using paired sample t-test with a level of $95 \%$. The results of this study gained an average prior to 34.7 kangaroo care method, after doing kangaroo care method 36.9. The mean before and after kangaroo care method 2.2273. Based on the analysis results showed pvalue (0.004) <a (0.05), It can be concluded no treatment effect kangaroo method to your body temperature low birth weight infants. Recommendations from this research is the kangaroo care method can be used as one $\angle B W$ care that can be done by the mothers in raising and maintaining body temperature.
\end{abstract}

Keywords : Kangaroo Mother Care, Body Temperature

\section{PENDAhUluan}

Kualitas hidup manusia dapat ditingkatkan dan sangat tergantung kepada kesejahteraan ibu termasuk kesehatan gizi dan dimulai sedini mungkin sejak janin didalam kandungan. Masalah kekurangan gizi bagi ibu hamil menjadi penyebab tingginya presentasi kasus berat bayi lahir rendah (BBLR). BBLR merupakan salah satu faktor penyebab kematian bayi khususnya pada masa perinatal sehingga memrlukan perawatan khusus.

Menurut data WHO kematian neonatal terjadi di negara berkembang. Amerika Serikat memiliki data prevalensi BBLR sekitar 7,3\% dari 2 juta persalinan, di Inggris $6 \%$ dari 2,3 juta persalinan dan di Afrika $12 \%$ dari 2,8 juta persalinan (Azari, 2013).

Menurut survei demografi kesehatan indonesia (SDKI) terdapat 7,5\% angka kejadian BBLR dari 2,7 persalinan pada tahun 2012. Indonesia merupakan negara yang memiliki prevalensi BBLR di semua provinsi. Provinsi Sulawesi Tengah angka BBLR tertinggi di Indonesia dengan presentase $16,8 \%$ sementara Sumatera Utara terendah dengan persentase $7,2 \%$ (RISKESDAS, 2013).

Sumber panas yang paling efektif bagi bayi baru lahir baik yang lahir cukup bulan maupun BBLR adalah kehangatan yang diberikan ibu dengan metode scin to scin 


\begin{tabular}{c|c|c}
\hline $\begin{array}{c}\text { JURNALPENELITIAN KEBIDANAN } \\
\text { \& KESPRO }\end{array}$ & VOL. 1 NO. 2 & $\begin{array}{c}\text { EDITION: NOVEMBER 2018 - } \\
\text { APRIL 2019 }\end{array}$ \\
\hline & http://ejournal.delihusada.ac.id/index.php/JPK2R & \\
\cline { 2 - 2 } RECEIVED: 16 JANUARI 2019 & REVISED: 12 MARET 2019 & ACCEPTED: 20 APRIL 2019 \\
\cline { 2 - 3 }
\end{tabular}

atau yang lebih dikenal dengan metode kanguru. Metode kanguru merupakan metode revolusi perawatan pada bayi kurang bulan (BKB)/BBLR yang bermanfaat untuk meningkatkan ikatan antara ibu dan bayi karena terjadinya kontak langsung ke kulit. Selain itu juga memulihkan bayi prematur dan meningkatkan rasa percaya diri bagi orangtua dalam merawat bayi premature (Suradi, 2012). Hasil penelitian menunjukkan bahwa terdapat hubungan metode kanguru dengan suhu tubuh BBLR di RSKD Ibu dan Anak Pertiwi Makasar (Anggreini, 2014). Hasil penelitian meyatakan bahwa ada pengaruh perawatan metode kanguru terhadap perubahan berat badan BBLR di ruang inap perinatologi RSUD dr. Achmad Mochtar Bukit Tinggi (Silvia dkk, 2015).

Data dari petugas Neonatus Intensive Care Unit (NICU) di Rumah Sakit GrandMed Lubuk Pakam, bahwa banyak kendala yang dialami diantaranya adalah tidak cukup tersedianya tenaga perawat yang telaten dan terampil untuk melaksanakan metode kanguru, waktu kunjungan yang terbatas, dan terpisahnya ruangan ibu dan bayi. Selain itu khususnya ayah belum dilibatkan sejak bayi lahir sampai pulang ke rumah untuk melakukan metode kanguru bergantian dengan ibu untuk menjalin interaksi sedini mungkin, belum ada ruangan tersendiri untuk PMK tetapi hanya tersedia kursi yang nyaman untuk ibu yang melakukan baju khusus kanguru yang tersedia belum mencukupi dan belum dilakukan penelitian tentang PMK di ruang NICU terhadap kontribusinya dengan peningkatan suhu tubuh BBLR.

\section{METODE}

Desain penelitian ini dengan rancangan pre eksperiment dengan one group pretestpostest design. Jumlah populasi sebanyak 40 orang yaitu seluruh BBLR yang dirawat di ruang NICU. Sampel dalam penelitian ini sejumlah 22 orang. Variabel independen yaitu perawatan metode kanguru. Variabel dependen yaitu suhu tubuh BBLR.
Pengumpulan data yang dilakukan menggunakan data primer yang berasal dari lembar observasi yang berisikan hasil pengukuran suhu tubuh dan data sekunder diperoleh dari data rekam medik. Analisa data yang digunakan adalah uji Paired Sample T-test.

\section{HASIL dan PEMBAHASAN}

Hasil analisis suhu tubuh pada bayi berat lahir rendah (BBLR) sebelum dilakukan metode kanguru yaitu dengan nilai rata-rata 34,7 dengan standar deviasi 1,211 terlihat pada tabel berikut:

Tabel 1: Pengukuran suhu tubuh pada bayi berat lahir rendah sebelum dilakukan perawatan

\begin{tabular}{ccc}
\hline $\begin{array}{c}\text { Suhu Tubuh } \\
\text { (Pre Test) }\end{array}$ & Mean & $\begin{array}{c}\text { Standar } \\
\text { Deviasi (SD) }\end{array}$ \\
\hline Suhu tubuh & 34,7 & 1,211 \\
\hline
\end{tabular}

Suhu lingkungan bayi sewaktu didalam kandungan sebesar $36^{\circ} \mathrm{C}-37^{\circ} \mathrm{C}$ dan segera setelah lahir bayi dihadapkan pada suhu lingkungan yang umumnya lebih rendah. Hal ini menyebabkan bayi akan kehilangan panas pada tubuh bayi atau yang disebut hipotermia. Hipotermia pada bayi terjadi karena ketidakmampuan untuk mempertahankan produksi panas pada tubuh bayi dan menggigil, sedikitnya lemak subkutan (lemak coklat) yang tidak memadai, dan sistem saraf pengatur suhu tubuh yang belum matang (Surasmi, 2012). Selain itu, daerah permukaan bayi akan menurun sehingga mempercepat hilangnya panas. Bayi BBLR terdapat jaringan adiposa sedikit dan kelenturan menurun sehingga memerlukan suhu lingkungan yang lebih panas untuk mencapai suhu yang normal (Proverawati, 2012).

Hasil analisis suhu tubuh BBLR sesudah dilakukan metode kanguru yaitu dengan nilai rata-rata 36,9 dengan standar deviasi 0,349 terlihat pada tabel berikut: 


\begin{tabular}{|c|c|c|}
\hline $\begin{array}{c}\text { JURNALPENELITIAN KEBIDANAN } \\
\text { \& KESPRO }\end{array}$ & VOL. 1 NO. 2 & $\begin{array}{c}\text { EDITION: NOVEMBER } 2018- \\
\text { APRIL } 2019\end{array}$ \\
\hline & http://ejournal.delihusada.ac.id/index.php/JPK2R & \\
\hline RECEIVED: 16 JANUARI 2019 & REVISED: 12 MARET 2019 & ACCEPTED: 20 APRIL 2019 \\
\hline
\end{tabular}

Tabel 2: Pengukuran suhu tubuh pada bayi berat lahir rendah sesudah dilakukan perawatan

\begin{tabular}{ccc}
\hline $\begin{array}{c}\text { Suhu Tubuh } \\
\text { (Post Test) }\end{array}$ & Mean & $\begin{array}{c}\text { Standar } \\
\text { Deviasi (SD) }\end{array}$ \\
\hline Suhu tubuh & 36,9 & 0.349 \\
\hline
\end{tabular}

Perawatan metode kanguru sebagai suatu cara perawatan untuk bayi BBLR melalui kontak kulit dengan kulit antara ibu dengan bayinya dimulai di rumah sakit dan dilanjutkan dirumah dengan tetap diberikan ASi supaya bayi tetap hangat (Surasmi, 2012). Perawatan metode kanguru merupakan suatu cara khusus dalam Perawatan bayi BBLR dengan metode kanguru yakni melakukan kontak langsung antara kulit bayi dengan kulit ibu untuk membantu perkembangan kesehatan bayi melalui peningkatan kontrol suhu, menyusui dan pencegahan infeksi (Proverawati, 2012).

Analisa statistik menunjukkan bahwa bahwa rerata pengukuran suhu tubuh pretest 34,7 dan suhu tubuh posttest 36,7 maka perbedaan atau selisih antara pengukuran suhu tubuh pretest dan postes adalah 2.2273 dengan standar deviasi (SD) 1.1977. Hasil Uji statistik didapatkan nilai $\mathrm{p}=0,004<(\mathrm{a}=$ $0,05)$ maka dapat disimpulkan bahwa Hipotesa $\mathrm{(Ha)}$ diterima yaitu ada pengaruh perawatan metode kanguru terhadap peningkatan suhu tubuh bayi berat lahir rendah.

Tabel 3: Rata-rata, standar deviasi, lower, upper, p-Value

\begin{tabular}{|c|c|c|c|c|c|c|}
\hline \multicolumn{3}{|c|}{ Mean Suhu Tubuh } & \multicolumn{3}{c|}{ Paired Test } & \multirow{2}{*}{ pValue } \\
\cline { 1 - 4 } Pre test & Posttest & Perbedaan & \multirow{2}{*}{$\begin{array}{l}\text { Standar } \\
\text { Deviasi }\end{array}$} & & U5\% Confidence Interval & \\
\cline { 5 - 6 } & & & Upper & Lower & \\
\hline 34,7 & 36,9 & 2.2273 & 1.1977 & 1.6962 & 2.7583 & 0.004 \\
\hline
\end{tabular}

BBLR mempunyai keterbatasan dalam pengaturan fungsi tubuhnya, salah satunya adalah ketidakstabilan suhu tubuh, sehingga dapat menyebabkan hipotermi pada bayi BBLR. Hipotermi dapat menyebabkan kesakitan bahkan kematian pada bayi BBLR. Salah satu solusi pencegahan hipotermi pada BBLR dengan melakukan perawatan metode kanguru dengan prinsip melakukan skin to skin contact sehingga bayi tetap hangat. Hal ini bertujuan untuk memberikan lingkungan hangat pada bayi dan meningkatkan hubungan ibu dengan bayinya (Anggriani, 2014). Hasil penelitian menunjukkan bahwa ada perbedaan yang bermakna lama hari rawat bayi BBLR yang diberikan metode kanguru dengan yang tidak diberikan (Astuti, 2018).

\section{KESIMPULAN}

Rata-rata suhu tubuh bayi sebelum dilakukan perawatan metode kanguru 34,7 dengan standar deviasi 1,211. Suhu tubuh bayi sesudah dilakukan perawatan metode kanguru rata-rata memiliki suhu 36,9 dengan standar deviasi 0,349. Ada perbedaan suhu tubuh sebelum dan sesudah perawatan metode kanguru pada bayi berat lahir rendah (BBLR) dengan $p$-Value yaitu 0.004 yang berarti nilai $p(0,004)<(a=0,05)$.

\section{DAFTAR PUSTAKA}

Utami (2013). ASI Eksk/usif. Trubus Agriwidya, Jakarta.

Azari, Dwana. 2013. Konseb Kebidanan. Fitrimaya, Yogyakarta.

RISKESDAS (2013). Perawatan Bayi Berat lahir Rendah (BBLR) dengan Metode Kanguru. Jakarta, HTA Indonesia.

Proverawati, Atikah (2012). BBLR (Berat Badan Lahir Rendah). Nuha Medika, Yogyakarta.

Suradi, (2012). Metode Kanguru sebagai Pengganti Inkubator untuk Bayi Berat Lahir Rendah. Jurnal Skripsi, Program 


\begin{tabular}{c|c|c}
\hline $\begin{array}{c}\text { JURNALPENELITIAN KEBIDANAN } \\
\text { \& KESPRO }\end{array}$ & VOL. 1 NO. 2 & $\begin{array}{c}\text { EDITION: NOVEMBER 2018 - } \\
\text { APRIL 2019 }\end{array}$ \\
\hline & $\frac{\text { http://ejournal.delihusada.ac.id/index.php/JPK2R }}{\text { REVISED: 12 MARET 2019 }}$ & \\
\cline { 2 - 2 } RECEIVED: 16 JANUARI 2019 & ACCEPTED: 20 APRIL 2019 \\
\hline
\end{tabular}

Dokter Spesialis Ilmu Kesehatan Anak FKUI/RSCM, Jakarta.

Anggriani, (2014). Hubungan Antara Metode Kangaroo Mother Care (KMC) Terhadap Suhu Tubuh BBLR di RSKD Ibu dan Anak Pertiwi Makassar. Jurnal Ilmiah Kesehatan Diagnosis Volume 4 Nomor 6 Tahun 2014.

Surasmi, Ika, (2012). Bayi dengan BBLR. Yogyakarta. Nuha Medika, Yogjakarta.

Zaida, (2013). Hubungan Kangaroo Mother Care (KMC) dengan Suhu Tubuh BBLR di Puskesmas Pembantu Blabak Wilayah Kerja Puskesmas Pesantren 1 Kota Kediri. Jurnal Skripsi, STIKES RS Baptis Kediri.

Silvia;Putri, Yelmi Reni;Gusnila, Elharisda, (2015). Pengaruh Perawatan Metode Kanguru terhadap Perubahan Berat Badan Bayi Lahir Rendah. Jurnal IPTEKS Terapan. Vol.9 No.1, Padang.

Astuti, Dwi, (2018). Efektivitas Kangoroo Mother Care terhadap Average Length Of Stay pada Bayi Berat Lahir Rendah. Jurnal Universitas Muhamadiyah Purwokerto. 